Portland State University

PDXScholar

7-16-1993

\title{
The Influence of Trichinella Spiralis Infection on Heat Shock Protein 72 Production in MRL++ Mouse Intestinal Cells
}

Lisa Ann Kilejian

Portland State University

Follow this and additional works at: https://pdxscholar.library.pdx.edu/open_access_etds

Part of the Biology Commons

Let us know how access to this document benefits you.

Recommended Citation

Kilejian, Lisa Ann, "The Influence of Trichinella Spiralis Infection on Heat Shock Protein 72 Production in MRL++ Mouse Intestinal Cells" (1993). Dissertations and Theses. Paper 4590.

https://doi.org/10.15760/etd.6474

This Thesis is brought to you for free and open access. It has been accepted for inclusion in Dissertations and Theses by an authorized administrator of PDXScholar. Please contact us if we can make this document more accessible: pdxscholar@pdx.edu. 
AN ABSTRACT OF THE THESIS OF Lisa Ann Kilejian for the Master of Science in Biology presented July 16, 1993.

Title: The Influence of Trichinella spiralis Infection on Heat Shock Protein 72 Production in MRL++ Mouse Intestinal cells.

APPROVED BY THE MEMBERS OF THE THESIS COMMITTEE:
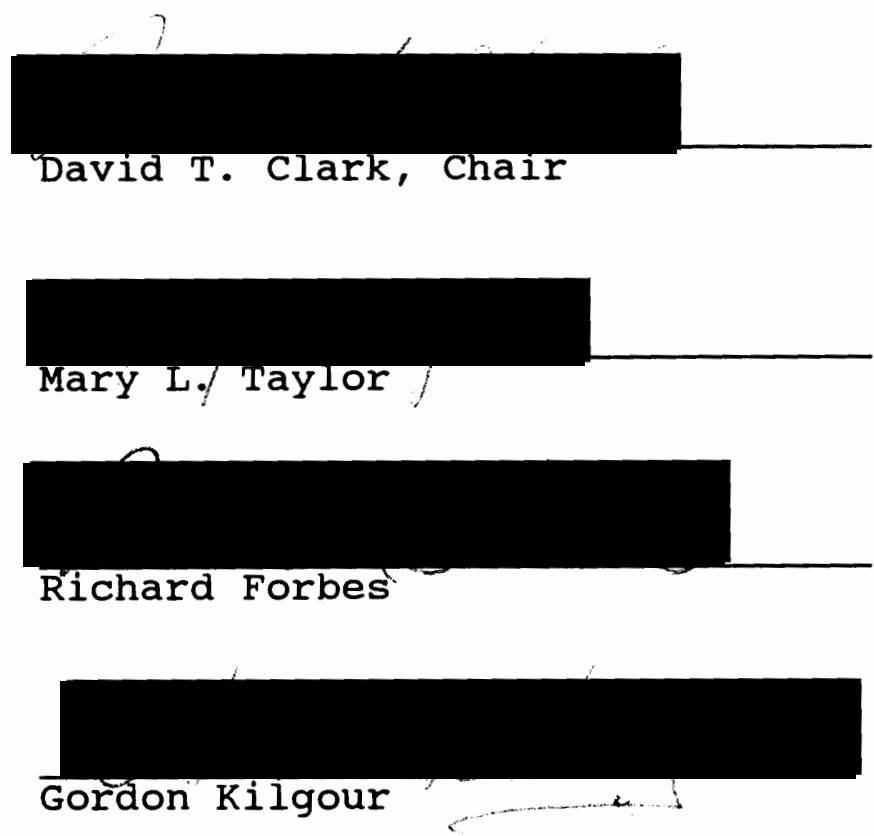

The production of Heat Shock Protein 72 , the inducible form of the highly conserved 70 kilodalton heat shock protein family, was investigated in MRL++ mouse intestine during the two weeks of a Trichinella spiralis infection. Within hours of an oral infection using the encysted 
Trichinella spiralis found in the diaphragm of an infected mouse, the larvae are released from the cyst in the stomach. They travel to the intestine and burrow into the epithelial layer of the intestine. The jejunum is the primary site of the intestinal phase of trichinosis (Despommier 1983). This stage of infection in the jejunum was the focus of this study.

Heat shock protein (HSP) synthesis is precipitated by stressful stimuli: in vitro by chemicals such as sodium arsenite and in vivo by cytoskeletal disturbance and/or toxic $\mathrm{O}_{2}$ radicals (Linquist 1986 ). The latter in vivo studies lend support to the inflammatory response induction of HSPs. Heat shock protein 72 (HSP72) is rarely expressed constitutively especially in non-primates and is a good indicator of various stresses. This study hypothesized that HSP72 would be induced by cells in the jejunum of the MRL++ mouse during a Trichinella spiralis infection due to the stress of the parasitic infection.

Different techniques were employed to investigate this hypothesis. Immunohistochemistry and immunoblots facilitated this study. Although immunoblots did not demonstrate HSP72 induction, immunohistochemical analysis suggested the presence of HSP72 in various cells in the lamina propria of the jejunal villi. 
THE INFLUENCE OF TRICHINELLA SPIRALIS INFECTION ON HEAT SHOCK PROTEIN 72 PRODUCTION IN MRL++ MOUSE INTESTINAL CELLS

by

LISA ANN KILEJIAN

A thesis submitted in partial fulfillment of the requirements for the degree of

MASTER OF SCIENCE

in

BIOLOGY

Portland State University

1993 
TO THE OFFICE OF GRADUATE STUDIES:

The members of the Committee approve the thesis of Lisa Ann Kilejian presented July 16, 1993.
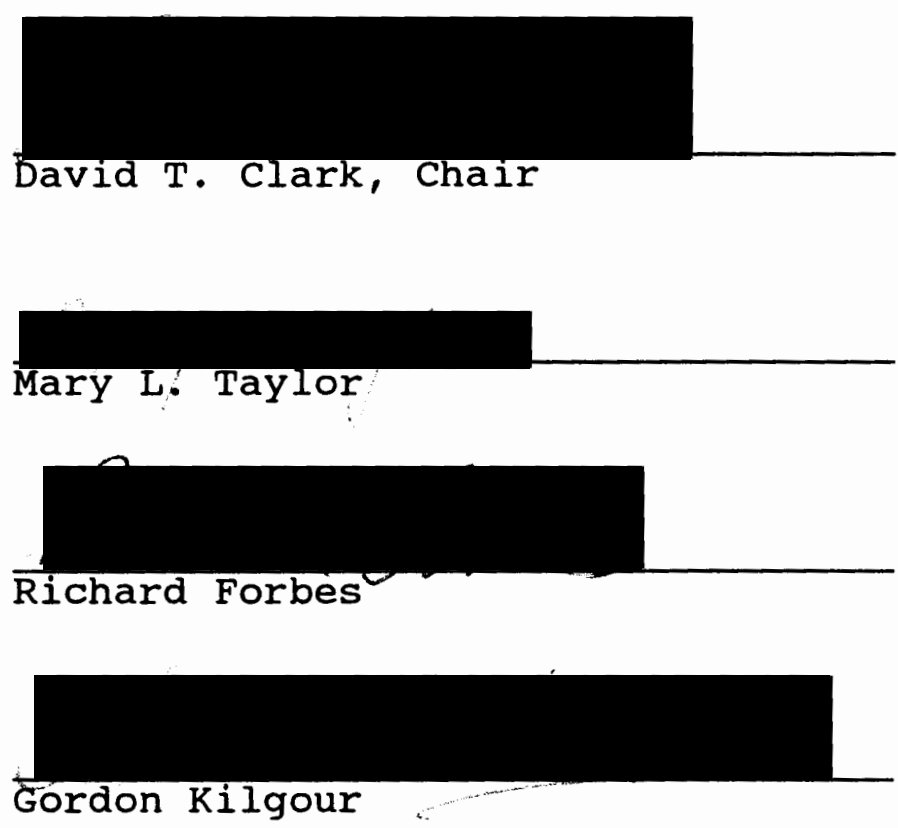

\section{APPROVED :}

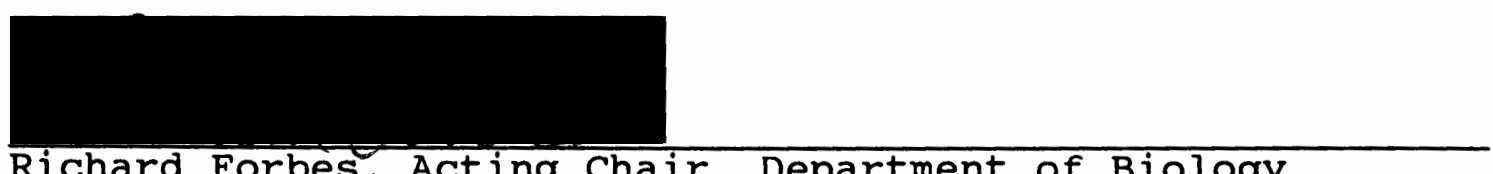

Richard Forbes, Acting Chair, Department of Biology

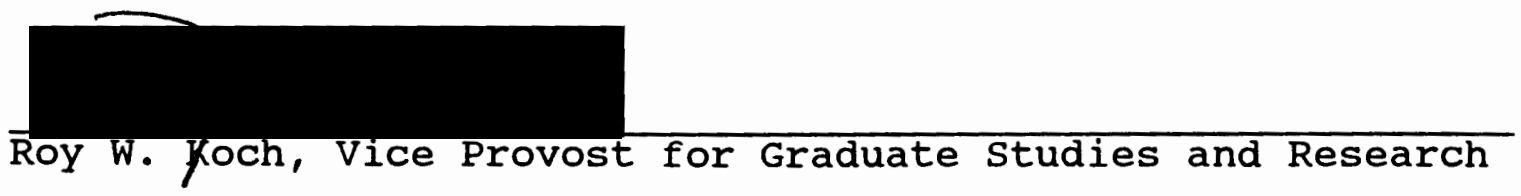




\section{ACKNOWLEDGEMENTS}

I thank all those who assisted me during my graduate program. I would especially like to thank my advisor, Dr. David Clark, for providing assistance and encouragement. I thank Barry Anderson for general support in the laboratory. I also thank Dr. Robert Millette for the HeLa cell cultures. Finally, I thank my graduate committee, Dr. Richard Forbes, Dr. Gordon Kilgour, and Dr. Mary Taylor, who offered their suggestions and time. 
TABLE OF CONTENTS

PAGE

ACKNOWLEDGEMENTS . . . . . . . . . . . . . . . . . . . .

LIST OF FIGURES . . . . . . . . . . . . . . . . . . . vi vi

INTRODUCTION • •

REVIEW OF LITERATURE . . . . . . . . . . . . . . . . . . 4

Life Cycle of Trichinella spiralis. . . . . . . . 4 Intestinal Phase Overview . . . . . . . . . . 5

Tissue Inflammation and Cellular Involvement. . . . 6

T lymphocytes

Helminth Induced Inflammation

Neutrophils and Eosinophils

Mast Cells

Infective Dose and Immune Response . . . . . . . 11

Heat Shock Protein Response . . . . . . . . 13

Heat Shock Proteins and Functions . . . . . . . 14

HSP and Immunity . . . . . . . . . . . . 15

Leukocytes . . . . . . . . . . . . . . . . 17

MATERIALS AND METHODS . . . . . . . . . . . . . . . . 20

Animals and Infection . . . . . . . . . . 20

Collection of Samples and Processing . . . . . 20

Positive and Negative Controls . . . . . . . . 21

Immunoblot Materials and Methods . . . . . . . 22

SDS-PAGE Method

Sample Preparation

Positive and Negative Control Samples 
Description of SDS-Polyacrylamide Gels

Western Blot Technique

Immunohistochemistry . . . . . . . . . . 27

Solution and Equipment Preparation

Dehydration, Parrafin Embedding and Sectioning

Immunodetection

RESULTS

SDS-PAGE and Immunoblot . . . . . . . . . 30

Localization of HSP72 via Immunohistochemistry . . 32

DISCUSSION • • . . . . . . . . . . . . . . . . . . . . . . 38

LITERATURE CITED . . . . . . . . . . . . . . . . . . . . . . . . . . . 43

APPENDICES

A STOCK SOLUTIONS FOR IMMUNOBLOT . . . . . . 48

B HEMATOXYLIN AND EOSIN PROTOCOL . . . . . . 52 


\section{LIST OF FIGURES}

FIGURE

PAGE

1. Specificity of antibody against HSP72 . . . 31

2. Hela cells (magnification, X1000) . . . . . 32

3. Intestinal villi tenth day of infection (magnification, X400) . . . . . . . . . 34

4. Intestinal villi (magnification, X400) . . 35

5. Infected intestinal villi incubated

in anti-HSP72 antibody demonstrating increasing immunoreactivity (magnification, X400) . . . 36

6. Infected intestinal villi demonstrating increasing immunoreactivity with HSP72 (magnification, X400) . . . . . . . . . 37 


\section{INTRODUCTION}

Trichinosis, a disease with world-wide distribution, is caused by the parasitic nematode, Trichinella spiralis. Sylvatic trichinosis describes the cycling of the disease between wild carnivores and their prey or carrion. In contrast, urban trichinosis describes the cycling of the disease among humans, rats and pigs (Cheng 1986). Trichinella is one of the least host-specific parasites in nature and can infect almost any mammalian host. one exception, the Chinese hamster, is subject only to the intestinal phase. This helminth lives as an intracellular parasite, excluding its migratory phases (Despommier 1983; Cheng 1986; Gould 1970; Wakelin 1984)

The host's immune response to the intestinal phase of a Trichinella spiralis infection is a complex phenomenon which involves a multitude of cells. The effects of the infection on the host are still not fully understood. The stress response experienced by host tissue, specifically heat shock protein (HSP) production requires more understanding of the interaction between the parasite and its host (Young 1990; Polla 1991).

In 1962, Ritossa described a "puffing" pattern on a salivary gland chromosome of Drosophila melanogaster after 
heat shock (Ritossa 1962). Later Tissieres, Mitchell and Tracy (1974) established the link between the increase in temperature and the synthesis of heat shock proteins which Tissieres called a "heat shock response" (Tissieres et al. 1974). Several years later, because of the many stimuli which elicit this "heat shock response," scientists more accurately describe it as a "stress" response (Welch and Suhan 1986). Such stimuli include environmental stressors such as amino acid analogues and transition heavy metals. Inflammation, ischemia, fever and oxidant injury also stimulate HSP production (Pappolla 1992; Polla and Kantengwa 1991; Vass 1988). Furthermore, normal cellular influences, including the cycle of cell division, may require stress proteins (Welch 1993).

Relatively recently, HSPs have been selectively linked with immune activities. The role of HSP in antigen presentation, immunoglobulin assembly, and as antigens themselves--which may involve them in autoimmunity--has contributed to this immunological role (Young 1990). Since this link between the HSP response and the immune system was recognized, there has been growing interest concerning stress proteins in infection and immunity. Very little has been done to ascertain the nature and extent of stress imposed on a host by a helminthic infection despite multiple studies of the stress response of the helminths themselves (Young 1990; Polla 1991). Accordingly, this study chose to 
examine the host's HSP response to a Trichinella spiralis infection to further elucidate the host's immune response. 


\section{REVIEW OF LITERATURE}

\section{LIFE CYCLE OF TRICHINELLA SPIRALIS}

The life cycle of Trichinella spiralis can be described starting with a susceptible host's ingestion of infective larvae encysted in skeletal muscle. Within minutes, digestion of the skeletal muscle in the stomach of the host releases larvae from their cyst. The free larvae are transported to the small intestine, primarily the jejunum, where they enter their intracellular niche--a group of columnar epithelial cells in the mucosa. Subsequently, fusion of these epithelial cell membranes forms a syncytium within which is the larva. The larva is approximately $1 \mathrm{~mm}$ in length and 35-38 microns in diameter. Since an average columnar epithelial cell is $32 \times 8.5$ microns, it must stretch to accommodate the worm with surprisingly no disintegration of the cell due to worm penetration (Despommier 1983).

Trichinella larvae grow and molt in their intestinal niche within the first two days after infection. Upon sexual maturity, mating ensues and embryos are seen in the female by the fifth day post infection (Gould 1970). After copulation, the adult males either die or pass out of the host; most adult worms, both male and female, are expelled 
by the fourteenth day post infection. Each pregnant females can support almost 1500 larvae.

Newborn larvae are observed in the intestinal cells on the fifth to seventh day of infection (Pond et al 1989; Gould 1970). Seventy percent of the newborn larvae are carried by the lymphatic vessels and the rest by veins to the heart (Despommier 1983; Cheng 1986). Cardiac contraction transports these larvae with the arterial blood. Upon arrival in the skeletal muscles--especially those of the diaphragm, jaws, tongue, larynx, and eyes--a special encystment of the larvae occurs in which each larva is enclosed by collagen and a rete of capillaries called the nurse cell. Over ten months to a year, calcium becomes deposited in the wall of the capsule. Encapsulated larvae may remain viable for as long as 25 to 30 years (Cheng 1986; Weatherly 1983).

\section{INTESTINAL PHASE OVERVIEW}

Despite the many studies examining the host's immune response to the intestinal phase of Trichinella spiralis, understanding of the mucosal immune response to Trichinella specifically and to intestinal helminths generally is incomplete. The intestinal phase of the Trichinella infection represents a complex and multifaceted process involving innate, non-specific defense mechanisms, cell mediated immunity, and humoral immunity (DeVos et al. 1992). 
The first lines of defense against the invading parasite are the non-specific defense mechanisms: gastric acidity, which actually digests the nurse cells and releases the infective larvae; mucus secretion; and intestinal motility (Befus 1986). Other non-specific components that are recruited include a surprising diversity of cell types such as granulocytes and mast cells. These cells are involved in the acute inflammatory response (Weatherly 1983) .

Soon after the infection, antigen-specific $B$ and $T$ cells are stimulated to proliferate and/or differentiate. Antigen-specific humoral immune responses, such as IgA and IgE antibodies, and cellular immune responses involving helper $\mathrm{T}$ cells and cytotoxic $\mathrm{T}$ cells are initiated. They may directly influence the development and/or survival of the parasite, or they can indirectly amplify or modulate the other, non-specific components of the host defenses (Befus 1986; Weatherly 1983)

\section{TISSUE INFLAMMATION AND CELLULAR INVOLVEMENT}

A list of responses is available to the host to combat a Trichinella infection. Elucidation of the host's mucosal immune response to this infection must include consideration of the sequence of events involving various immune system cells and subsequent morphological changes of the intestine. 


\section{T lymphocytes}

Shortly after a primary Trichinella infection, a lymphoblast response results in large numbers of dividing $T$ cells within the mesenteric lymph nodes. This response is to all the worm antigens, which include the parasite wall and excretory/secretory products. Antigen uptake is achieved by M cells of Peyer's patches and epithelial cell junctions during inflammation (Wakelin 1984). In addition to these mesenteric dividing $T$ cells, there is a change in the homing patterns of $\mathrm{T}$ lymphoblasts which originate in gut-associated lymphoid tissue (Wakelin and Denham 1983; Castro 1989).

A notable consequence of $T$ cell involvement is $T$-cell mediated villous atrophy and crypt elongation reported in the intestine of Trichinella infected mice. Goblet cell hyperplasia, which is seen in Trichinella infection, has been linked to $\mathrm{T}$ cells in a Nippostrongylus brasiliensis infection, another enteric parasite (Castro 1989). Also, enhanced mucus release in the gut of Trichinella-infected mice, a non-specific response, is modulated and further stimulated by $T$ cells (Befus 1986; Kumar et al. 1989).

The mechanism by which $\mathrm{T}$ cells mediate immunity against intestinal parasites is not clearly established. Their effects--epithelial layer alterations, acute inflammation and enhanced mucus release--are detrimental to parasite survival and result in the ultimate expulsion of the adult intestinal parasite from the gut approximately two weeks 
later (Castro 1989; Kumar et al. 1989; Pond et al. 1989).

Helminth Induced Inflammation

Inflammation, a "tissue's reaction to injury", is manifested by infiltration of the mucosa by a variety of cells including granulocytes; by such changes in mucosal architecture as crypt hyperplasia, villous atrophy and enhanced epithelial turnover; and by increases in the levels of a number of enzyme of leukocyte and mast cell origin. studies have shown a causal relationship between inflammation and expulsion of the adult worms due to their inability to become established and to survive in an inflamed intestine regardless of their own state (Moqbel 1986; Weatherly 1983; Wakelin 1986).

\section{Neutrophils and Eosinophils}

Within a few hours of the Trichinella infection cellular infiltration and mediator release ensue. Inflammatory cells involved in this immune response, in the order of their appearance, are neutrophils, mast cells and eosinophils. Neutrophils have the least pro-inflammatory role in Trichinella infections. Eosinophils infiltrate the mucosal layer in large numbers during the infection, but no close contact between parasites and eosinophils has been observed (Moqbel 1986). Despite their infiltration and classic role in intestinal immunity, depletion of the eosinophil product, lysophospholipase B, had no major effect 
on worm expulsion (Wakelin and Denham 1983). Nevertheless, antiserum against these eosinophils in Trichinella-infected mice yielded an increase in cyst formation in another study (Roitt 1991).

The neutrophil and eosinophil response is associated with increased levels of their products myeloperoxidase and lysophospholipase B respectively. Myeloperoxidase, a phagocytic enzyme, eventually produces singlet oxygen while lysophospholipase B is associated with the ultimate production of prostaglandins (Roitt 1991). Singlet oxygen is a toxic $\mathrm{O}_{2}$ species which is responsible for a wide variety of undesirable oxidation reactions leading to oxidative destruction of vital cell components as well as a microbicidal effect (Fridovich 1978).

\section{Mast Cells}

The major cell involved in the mucosal immune response to Trichinella infection is the mast cell, which appears four days post infection. Intestinal mast cells are histochemically, biochemically and functionally distinct from mast cells widely distributed in other tissues in the body (Befus 1986). Mast cells in the gastrointestinal tract belong to two main types-mucosal mast cells, which are found predominantly in the lamina propria, and connective tissue mast cells, which are located in the serosal layers of the small intestine. Mucosal mast cells increase in 
number as the infection continues, peak about the time of worm expulsion begins (day eight/nine), and then decline. This mast cell hyperplasia represents another $\mathrm{T}$ cell mediated response (Wakelin and Denham 1983)

Hypersensitivity-like reactions, such as mast cell degranulation occur not only with secondary infections but also during the primary infection (Zhang 1990). Degranulation of mast cells occurs when antigenic stimulation results in crosslinking of the cell-bound IgE, or IgGl on the mast cell. Various reports have demonstrated that many different stimuli, not just IgE, induce mast cell mediator release. For instance, neurointestinal peptides, macrophage-derived and $T$ lymphocyte-derived factors and parasitic antigens themselves have been shown to induce secretions (Roitt 1991; Befus 1986).

Several mast cell factors are released upon appropriate stimulation. These cellular mediators are involved in sundry potential inflammatory events. Factors involved in cellular infiltration and activation include leukotriene B4, 5-hydroxyeicosatetraenoic acid, eosinophil chemotactic factor of anaphylaxis, neutrophil chemotactic activity and histamine. Mediators responsible for mucosal edema are histamine, sulphidopeptide-A leukotrienes, prostaglandins, and bradykinin. Epithelial shedding is enhanced by a mucosal mast cell product, RMCP-II. Finally, histamine, prostaglandins and serotonin are involved in 
mucus hypersecretion and increased gut motility (Befus 1986; Moqbel 1986; Wakelin and Denham 1983). Consequently, mast cells, which dramatically increase in number a few days after a primary infection (>900 cells), peak around day ten ( $>1100$ cells) and slowly decline to 100 cells in 35 days, have a very significant role during Trichinella spiralis infection (Castro and Bullick 1983).

\section{INFECTIVE DOSE AND IMMUNE RESPONSE}

Study of the host's immune response to Trichinella infection in the intestinal phase must consider the dose of the initial infection. Bell and Liu (1988) conducted a study which categorized rejection as strong, intermediate and weak. Rejection was weak with doses of less than 50 muscle larvae per mouse. Rejection time was shortest in the range of 50-100 muscle larvae/mouse and an asymptotic increase in rejection time occurred with increasing dose up until deaths due to migratory phase of the infection. Nevertheless, the most efficient rejection--maximum number of worms rejected in a given period--occurs with very high dose ( 800 worms). Host genotype determines the time taken to rejection at any dose above 50 muscle larvae, primarily by modifying the time of initiation of rejection. Bell and Liu (1988) suggested that this delay in rejection may be due to an unspecified amount of damage which must be inflicted on the worm before its expulsion. Another study, however, 
found that worms transplanted into an infected host were expelled with the worms of the initial infection (Wakelin and Denham 1983) .

DeVos, Danell and Dick (1992) also found that the mucosal immune response to Trichinella spiralis is dose dependent. The primary isotype in the mouse's response was IgA; however, IgG increased slightly. A decrease in fecundity and worm length corresponded to the immunoglobulin response in Swiss Webster mice and Balb/c mice, yet expulsion was not directly correlated to the immunoglobulin response in $\mathrm{Balb} / \mathrm{C}$ mice. Other researchers originally described IgA as the dominant isotype. Nonetheless, the number of IgA plasma cells unlike IgM and IgG cells did not change significantly. Although not thoroughly investigated regarding its effects on Trichinella spiralis, serum IgA has been implicated in the inflammatory response--the initiation of the neutrophil respiratory burst and degranulation of eosinophils. Therefore, IgA may have a more significant effect on this parasite than previously was thought (Devos et al. 1992)

In conclusion, the mucosal host immune response to Trichinella spiralis is a complex phenomenon that involves multiple interacting immune system cells and mediators. T cells seem to initiate the overall response, and mast cells continue the response by producing mediators which attack the parasite. Ultimately the parasite is expelled because 
of this powerful specific cell mediated immune response, non-specific immune responses and humoral antibody responses which include IgG, IgA and IgE.

\section{HEAT SHOCK PROTEIN RESPONSE}

The heat shock protein response appears to be a universal response of all cells from bacteria to humans when exposed to stressful stimuli. "stresses" include heat, the original stimulus for which the "heat" shock response was named, and several other inducers. For example, heavy metals and sodium arsenite are in vitro inducers while ischemia and oxidative stress are in vivo inducers (Linquist 1986)

Sundry highly conserved proteins of different molecular weights are synthesized in response to the various stimuli. Many researchers categorize these proteins into different groups: heat shock proteins proper (HSP), which are specifically induced by heat; glucose regulated proteins (GRP), for which the inducers are glucose deprivation or calcium ionophores; and low molecular weight proteins, such as ubiquitin which is responsible for protein degradation (Welch 1991). Other authorities divide the stress proteins into more distinct categories such as HSPs, GRPs, ubiquitin, metallothioneins and oxidation-specific stress proteins, such as heme oxygenase (Donati et al. 1990). All proteins may be classified by their molecular weights. The most 
notable HSP families include the 90kD family; the 70kD family which is the most highly conserved and well-studied; and the $60 \mathrm{kD}$ family. The lower molecular weight proteins have not been studied as extensively as the others.

\section{HEAT SHOCK PROTEINS AND FUNCTIONS}

Heat shock proteins (HSPs) not only are induced during times of stress as originally believed but also are expressed constitutively in the cell suggesting a fundamental role in the cell's normal functioning and survival(Craig 1993). John Ellis of the University of Warwick called HSPs "molecular chaperones" (Welch 1993). These molecules "facilitate the folding and assembly of other polypeptides but are not part of the finished complex" (Takenaka and Hightower 1992). HSPs are also responsible for preventing or facilitating protein/protein interaction (aggregation of proteins), and disassembly of proteins (degradation of proteins) (Craig 1993). All HSPs show a high affinity for adenosine triphosphate (ATP) (Welch et al. 1991), and hydrolysis of ATP is responsible for allowing the initiation and completion of HSP's interaction with other proteins (Burel et al. 1992; Chappell 1986).

Although the functions of heat shock proteins show general similarities-molecular chaperoning and protein degradation (Burel, et al. 1992; Feige and Mollenhauer 1992), each family shares a more common mechanism of action. 
For instance, HSP $90 \mathrm{kD}$ are known to prevent steroid receptor and DNA interaction without the presence of a stimulus/hormone in order to preclude uninstructed stimulation. The 70kD family contains the largest most conserved and well-studied proteins. This family has been noted for a variety of functions including protein folding and assembly of other proteins and uncoating of clathrin vesicles (Welch 1991). This family includes HsP73, a constitutive protein; HSP72, an inducible protein; and GRP78 (Bip), known as Bip (Binding protein). The HSP 60kD family shares most functions with HSP70 and is involved in autoimmunity. The lower molecular weight proteins are $45 \mathrm{kD}$ HSP, which has a high affinity for collagen, and ubiquitin (8 kD), which is involved in the degradation of proteins (Burel et al. 1992).

\section{HSP AND IMMUNITY}

HSPs have been linked with the immune response. They are involved in immune functions such as immunoglobulin assembly and antigen presentation. The stress protein GRP78, binds to the heavy chain of immunoglobulins in pre B cells and thus aids in immunoglobulin assembly. This protein is located in the endoplasmic reticulum (Linquist and Craig 1988)

During antigen processing in an antigen presenting cell (APC) the HSP 70 assists in anchoring the processed antigen 
onto the APC cell surface while facilitating interaction with MHC II and/or the T cell receptor. Both GRP 78 and HSP 70 bind peptides which elicits hydrolysis of ATP when releasing the bound peptides (Feige and Mollenhauer 1992) Furthermore, two HSP 70kD genes are located within the human MHC complex region. Association with the MHC complex, and binding then releasing antigen in an ATPase fashion, may suggest that HSP 70kD does not only play a role in antigen presentation but also may facilitate antigen transport to the APC cell surface (Young 1990).

Inflammation may be a general stimulus connected to HSP production. During inflammation an increase in heat occurs in the region of insult resulting from the infiltration of a variety of cells. An increase in the permeability of the vasculature allows the polymorphonuclear neutrophils (PMNs), eosinophils (Kaufmann 1990; Polla and Kantengwa 1991), macrophages, and mast cells to enter the area. Another characteristic of inflammation is connective tissue remodeling and later deposition of excess or abnormal extracellular proteins (Polla and Kantengwa 1991).

Hightower and White (1981) were among the first researchers to suggest a connection between inflammation and the production of HSPs. After studying cell and tissue cultures that had been exposed to a variety of stressors resulting in HSP production, they concluded that inflammatory mediators may also induce HSP synthesis. 
Tissue acidification, prostaglandin synthesis which may precipitate free oxygen radicals, hyperthermia, damaged and/or abnormal proteins may be responsible for HSP production (Hightower and White 1981). Most if not all of these tissue insults are involved in Trichinella spiralis intestinal infection (Cheng 1986; Gould 1970).

Many of these processes of inflammation now have been experimentally linked to HSP production: heat (fever), damaged or abnormal cellular proteins, and leucocytes which produce oxygen free radicals. Heat which may cause protein degradation is a classic stimulus for HSP production (Polla 1988). An accumulation in abnormal proteins due to degradation of toxic oxygen species is another stimulus for HSP production (Beckmann 1990).

\section{LEUKOCYTES}

A major feature of inflammation is the infiltration of leukocytes which potentiate oxidative stress as a consequence of reactive oxygen species. These toxic oxygen products have been definitively linked with increased HSP production. Reactive $\mathrm{O}_{2}$ species may produce DNA strand breaks and alter proteins; abnormal proteins are a key stimulus for HSP production (Polla and Kantengwa 1986). The leukocytes--specifically neutrophils, monocytes/macrophages, and eosinophils--can produce and secrete toxic oxygen species after initiating a respiratory burst (Roitt 1991). 
A respiratory burst is the leukocyte's burst of oxygen consumption resulting in the conversion of oxygen to superoxide anion, hydrogen peroxide, singlet oxygen and hydroxyl radicals. These products represent the toxic oxygen species which may eliminate the engulfed microbe located in the phagosome (Roitt 1991). The respiratory burst and the subsequent release of the toxic metabolites occurs within this phagosome in the cytoplasm of neutrophils and monocytes/macrophages.

Eosinophils also produce an impressive respiratory burst; however, they damage or kill the microbe extracellularly rather than in a phagosome. Although the metabolites produced may kill the infective organism, they are also damaging to the host tissue. Consequently, at least in monocytes, macrophages and neutrophils, HSPs are "antioxidants" that protect cells from their own damaging metabolites (Roitt 1991; Polla 1988).

Other inducers or augmenters of HSP production regarding the inflammatory response include bacterial products, cytokines (eg., IL2, TNF) and possibly metabolites of the arachidonic acid cascade. Monocytes and neutrophils were the cells employed in many of these studies. $T$ cells were also induced by IL2 to synthesize HSP70 upon stimulation (Ferris et al. 1988; Fincato et al. 1991; Polla and Kantengwa 1991).

Kaufmann (1990), Young (1990) and Polla (1991) all 
mention the lack of experimental investigation regarding the probable host HSP immune response when encountering an intracellular parasite. I chose to investigate this response in a MRL+t host when exposed to the intestinal phase of the parasite Trichinella spiralis. The inducible form of the HSP 70kD family, HSP 72kD, was chosen because its presence would indicate a selected stress response while other heat shock members are constitutive. Furthermore, the HSP 70kD family is the most highly conserved of all heat shock protein families; an antihuman monoclonal antibody could be used in this study. simply stated, I proposed that a Trichinella spiralis infection would induce HSP72 production in the MRL++ mouse jejunal cells. 
MATERIALS AND METHODS

ANIMALS AND INFECTION

Animal protocols used in this work were approved by the Animal Care Committee at Portland State University. Six-to eight-week-old male MRL++ mice (Mus musculus Linn.) were used throughout the study. An older MRL++ mouse infected with Trichinella spiralis was killed and a midline laparotomy was performed to extract the encysted diaphragm. The diaphragm was divided into equal sections each of which contained approximately 90-130 cysts which was determined by examination of the infected diaphragm under a dissecting microscope. Each of thirteen mice was infected with the encysted piece of diaphragm. To ensure rapid digestion of the infected tissue, the mice were starved for approximately fifteen hours prior to infection. The Trichinella spiralis used for this research were the Indiana strain isolated from a herd of domestic swine (Sus scrofa Linn.) heavily infected with the parasite (Kazacos et al. 1986). The strain was maintained through passage of the parasite in rats and mice.

\section{COLLECTION OF SAMPLES AND PROCESSING}

Following the Trichinella spiralis infection, one infected mouse was killed each day for fourteen days to 
obtain samples. The mouse killed on the thirteenth day was an uninfected mouse, a control. To clear the intestine on the day of killing, each mouse was deprived of food but not water five to seven hours before it was killed. The mice were killed by cervical dislocation. A midline laparotomy was performed, and the small intestine was freed from the mesentery and measured. The small intestines of all the mice were approximately $50 \mathrm{~cm}$. The small intestine was immediately transferred to a petri dish on ice which contained 2-3 mI PBS solution. Several $1 \mathrm{~cm}$ sections were removed from the intestine, but final studies focused on the jejunum--the primary site of the intestinal phase of Trichinella spiralis infection. Each $1 \mathrm{~cm}$ sections removed from the jejunum immediately was placed in a cryogenic tube to be frozen in liquid nitrogen or was fixed in $10 \%$ formalin.

\section{POSITIVE AND NEGATIVE CONTROLS}

After the samples of the small intestine were gathered and processed, a kidney was removed from the mouse and placed in a cryogenic tube to be frozen in liquid nitrogen. This tissue served as a negative control during the immunoblot analysis. A positive control for the immunoblot and for the immunohistochemistry was the Hela cells, a strain of cervical cancer cells which are known to produce HSP72 both without extrinsic stimulation and when heat 
shocked. In this study, the HeLa cells, which were kindly provided by Dr. Robert Millette, were heat shocked for two hours at $43^{\circ} \mathrm{C}$. and then allowed to recover overnight at $37^{\circ}$ c., their normal growth temperature. The next day the cells were harvested to be used for immunoblotting or for immunohistochemical technique. The HeLa cells were raised in Delbeco's Modified Eagle's Media with $10 \%$ inactivated calf serum. The media was also kindly provided by $\mathrm{Dr}$. Robert Millette.

\section{IMMUNOBLOT MATERIALS AND METHODS}

Preparation for the immunoblot required further processing of the sample tissue to use for the Laemmli SDS-polyacrylamide gel electrophoresis (SDS-PAGE) technique (Laemmli 1970), performing the actual Western Blot, and then developing the result with a chosen substrate. The Western Blot was facilitated by using the method by Towbin, Staehelin and Gordan (1979). Most techniques were slightly modified. Fresh stock solutions were mixed to expedite each of these steps (see Appendix A).

\section{SDS-PAGE Method}

The Hoeffer Tall Mighty Small 7 and $11 \mathrm{~cm}$ Vertical Slab Unit was used to run $8 \times 11 \mathrm{~cm}$ minigels (Hoeffer Scientific Instruments). The electrophoretic technique was carried out by the system of Laemmli using a stacking gel (3\% 
acrylamide) and a resolving gel (10\% acrylamide). The resolving gel was mixed after sealing the plates with $2.5 \%$ agar. It consisted of $0.15 \mathrm{ml} 10 \% \mathrm{SDS}, 3.75 \mathrm{ml}$ resolving buffer, $5 \mathrm{ml}$ acrylamide and $6 \mathrm{ml}$ double deionized water $\left(\mathrm{ddH}_{2} \mathrm{O}\right)$ mixed and degassed for 15 minutes. Seventy-five microliters ( $u l$ ) ammonium persulfate (APS) and $15 \mathrm{ul}$ $\mathrm{N}, \mathrm{N}, \mathrm{N}^{\prime}, \mathrm{N}^{\prime}$-tetramethylethylenediamine (TEMED) were added to initiate the crosslinking--polymerization. Immediately the solution was pipetted with a drawn-out glass Pasteur pipette between the vertical glass plates and topped with isopropyl alcohol to eliminate inhibition of polymerization.

After 30 minutes, the stacking gel was prepared in the same manner using $0.15 \mathrm{ml}$ SDS, $3.75 \mathrm{ml}$ stacking gel buffer, $2.25 \mathrm{ml}$ acrylamide and $9 \mathrm{ml} \mathrm{ddH}_{2} \mathrm{O}$. These solutions were mixed and degassed for 15 minutes before adding 75 ul APS and $7.5 \mathrm{ml}$ TEMED. The isopropyl alcohol was poured from the polymerized gel and rinsed with the stacking gel solution. The stacking gel solution was then poured and allowed to polymerize for 30 minutes. A ten lane comb was inserted after pouring the gel. The comb was later removed, the electrophoretic buffer was poured in the upper and lower chambers, and the gel was allowed to pre-run for 2-3 hrs during which time the sample was prepared. 


\section{Sample Preparation}

All tissues immediately were placed in a petri dish on ice, and preparations were performed in the cold room. Samples frozen in liquid nitrogen were removed from the cryogenic tubes and placed in a glass homogenizer with 100 ul RIPA buffer (Suzuki and Wantanabe 1992), 100 ul DNAase I (100 ug/ml), 95 ul lysis buffer. Each sample was homogenized for approximately three minutes before being boiled for 5 minutes. The samples were then centrifuged at $15,000 \mathrm{~g}$ for 3 minutes and $100 \mathrm{ul}$ supernatant was placed in a new Ependorf tube. To each sample 7 ul of 2betamercaptoethanol was added and the samples were boiled for another 3 minutes. Three microliters of bromophenol blue was added, and the samples were then loaded into the gel wells and run at 25-50 $\mathrm{V}$ until the dye line reached the bottom of the gel. Molecular weight marker standards were always included as a reference.

\section{Positive and Negative Control Samples}

Kidney tissue from uninfected mice served as a negative control and was processed in the same manner as other tissues. The positive control was the HeLa cells. They were harvested after being heat-shocked for two hours the previous evening. The media was poured off of the cells which were in a T75 flask cell culture and were rinsed four times with PBS. The Hela cells were then scraped from the bottom of the T75 flask, after adding $1 \mathrm{ml}$ sample/lysis 
buffer and $100 \mathrm{ul}$ DNAase I, and placed in a pyrex glass tube. The Hela cells were boiled 5 minutes to lyse cells and inactivate DNAase I. They were then centrifuged low speed in the cold room after being transferred to an Ependorf tube. Samples were then aliquotted into $50 \mathrm{ul}$ tubes and frozen at $-70^{\circ} \mathrm{C}$. For sample preparation only $2 . .5$ ul of 2-betamercaptoethanol was added to the $50 \mathrm{ul}$ Hela sample before boiling and loading onto the gel.

Description of SDS-Polyacrylamide Gels

One of the SDS-polyacrylamide gels consisted of five lanes containing molecular weight markers, mouse intestine day 8 and day 9 post infection, and an uninfected mouse kidney. The next five lanes of the ten-lane gel duplicated these sample lanes. The gel was halved and one section was stained in Coomassie brilliant blue R250 for four to six hours and the other half was used for a Western blot. Another gel was loaded with molecular weight markers, uninfected intestine, heat shocked HeLa cells and infected intestinal samples from days $2,4,5,6,7,13$ and 14 . The sample from day 13 was tissue from an uninfected mouse which served as another uninfected intestine control. This gel was not stained in Coomassie brilliant blue R250 but was used only for a Western blot. 
Western Blot Technique

After running the polyacrylamide gel, the proteins were blotted onto a nitrocellulose sheet. First, the gel was peeled from the plates and rinsed in Western electrophoretic buffer to remove excess SDS. Three Whatman number one sheets and the nitrocellulose paper were also rinsed in this buffer before sandwiching between the rinsed scotch-brite pads and placed in the Western blotting apparatus. The gel was blotted overnight at 5-10 V/75 mamp.

When the transfer was complete, nitrocellulose filter paper was removed and blocked with $3 \%$ nonfat dry milk for 1.5 hours. The paper was then rinsed quickly in PBS and reacted with the monoclonal alkaline phosphatase conjugated primary antibody (SPA-810AP) for 2.5 hours purchased from stress-Gen. The primary antibody was diluted 1:500 (40 ul primary antibody, $20 \mathrm{ml}$ PBS, $.01 \mathrm{~g}$ sodium azide and $0.06 \mathrm{~g}$ BSA) .

After reacting with the antibody, the paper was washed five times with $50 \mathrm{ml}$ PBS to remove any excess antibody. The paper was then reacted with the substrate 5-bromo-4-chloroinodolyl phosphate/nitro blue tetrazolium, Tris buffer and $\mathrm{MgCl}_{2} \mathrm{BCIP} / \mathrm{NBT}$ (Sigma). When the reaction was complete, distilled water was added to stop the reaction, and the paper was allowed to dry. 


\section{IMMUNOHISTOCHEMISTRY}

Immunohistochemistry involves fixing fresh tissue, embedding it in paraffin, sectioning it, and immunostaining it for the protein of interest. Methods were taken from Ann Preece (1972) and were modified to accomplish the following.

\section{Solution and Equipment Preparation}

A solution was prepared consisting of five milliliters of polylysine for every $95 \mathrm{ml}$ distilled water. Slides were soaked for ten minutes in this solution and allowed to dry. The microtome knife was sharpened before use. Glass plates were honed to smooth their surfaces before they were used to sharpen the knife. Coarse solution was applied to the knife and plates during the two 25-minute sharpening sessions. Fine solution was then applied for another two sharpening sessions.

\section{Dehydration, Paraffin Embedding and Sectioning}

Tissues were fixed in $10 \%$ neutral buffered formalin and dehydrated in a graded alcohol series $(70 \%, 85 \%, 95 \%, 100 \%)$. Each dehydration step was repeated two times for 15 minutes except that dehydration in $100 \%$ ethanol was repeated three times. The tissues were then placed in xylene/100\% alcohol for 15 minutes for two changes then $100 \%$ xylene for fifteen minutes for two changes before being placed in melted paraffin $\left(60^{\circ}\right)$ for 30 minutes for three changes. Tissues 
collected on different days of the infection were transferred to plastic containers with melted paraffin, dropped into cold water to increase the speed of solidifying the paraffin, and allowed to dry.

Sections five microns thick were made and the tissue was placed in a $43^{\circ} \mathrm{C}$. water bath before being mounted on a polylysine slide. The tissue on the slide was first air dried overnight then heat dried at $59^{\circ} \mathrm{C}$. for 30 minutes.

\section{Immunodetection}

Tissue mounted on polylysine slides was deparaffinized in three changes of xylene for three minutes each, three changes of absolute alcohol for one minute each, and rehydrated through $95 \%, 80 \%$ and $70 \%$ ethanol to running tap water. Slides were then placed in 5\% DMSO/PBS for ten minutes followed by a five minute wash in PBS. Tissue sections on a microscope slide were then encircled with a Pap-Pen. Digestion of the tissue sample was accomplished with $1 \mathrm{mg} / \mathrm{ml}$ or $0.1 \%$ Trypsin (Sigma) containing $150 \mathrm{~mm}$ Tris, $\mathrm{pH} 7.6$ at $25^{\circ} \mathrm{C}$. for ten minutes. Protein blocking $(5-10$ minutes; overnight for control--infected intestine day 10 and heat shocked HeLa cells) was supplied by the Lipshaw Immunostaining Kit while the primary monoclonal antibody was applied overnight at room temperature to all samples other than controls. Slides were washed gently with a stream from a wash bottle of PBS buffer and then washed in three changes 
of PBS buffer for one to two minutes each. Fresh NBT\BCIP solution was made from tablets containing $0.15 \mathrm{mg} / \mathrm{ml} \mathrm{BCIP}$, $0.30 \mathrm{mg} / \mathrm{ml} \mathrm{NBT}, 100 \mathrm{mM}$ Tris buffer and $1 \mathrm{mM} \mathrm{MgCl}_{2}$ (Sigma). The slides were allowed to incubate for twenty minutes. Slides were then washed in water for two minutes and a coverslip was mounted with GelTol mounting media (Lipshaw). 
RESULTS

SDS-PAGE AND IMMUNOBLOT

The crude intestinal extracts stained in coomassie brilliant blue R250 demonstrated that ample proteins were present for protein banding in both day 8 and day 9 post infection, the uninfected kidney and the Hela cells. (Figure 1A). In the Western Blot (Figure 1B) which contained the sample load as Figure $1 \mathrm{~A}$, the anti-HSP72 antibody recognized the control lane consisting of homogenized heat shocked HeLa cells. The other lanes which contained intestinal infection days 8 and 9 and a kidney demonstrated no immunoreactivity.

Another Western Blot loaded with uninfected intestine, infected intestinal samples from days $2,4,5,6,7,13,14$, heat shocked Hela cells and molecular weight markers showed similar results. Again, the only immunoreactivity demonstrated was the heat shocked Hela cells (Figure 1C). 


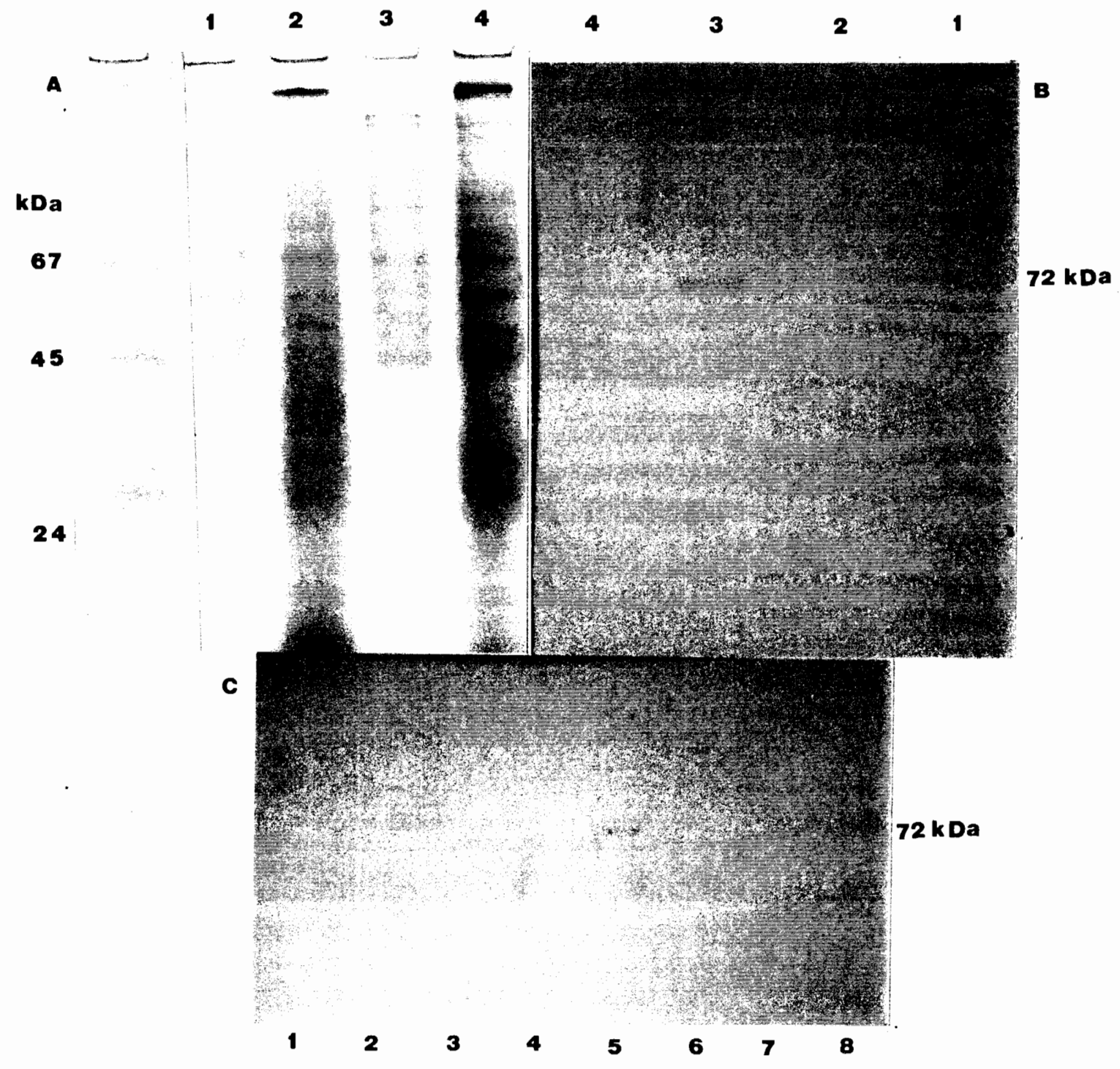

Figure 1. Specificity of antibody against HSP72 . (A) SDS-polyacrylamide (10\%) gel stained with Coomassie brilliant blue R-250. Numbers on the left indicate molecular weight markers in $\mathrm{kDa}$. Immunoblot with mouse alkaline phosphatase conjugated antibody (Stress Gen: SPA 810 AP) against homogenized samples. Lane 1. Mouse kidney. Lane 2. Infected intestine day 9. Lane 3. Heat shocked HeLa cells. Lane 4. Infected intestine day 8. (C) Immunoblot with SPA $810 \mathrm{AP}$ against infected mouse intestine. Lane 1. Infected intestine day 14. Lane 2. Uninfected intestine day 13. Lane 3. Infected intestine day 7. Lane 4. Infected intestine day 6. Lane 5. Heat shocked HeLa cells. Lane 6. Infected intestine day 5. Lane 7. Infected intestine day 4. Lane 8. Infected intestine day 2 . 
LOCALIZATION OF HSP72 VIA IMMUNOHISTOCHEMISTRY

Although SDS-PAGE analysis yielded negative results, immunohistochemical analysis was still performed. Tissues were placed in $10 \%$ formalin, dehydrated, embedded in paraffin and sectioned at 5 microns. Hela cells which were embedded in the same manner as intestinal tissue served as a positive and negative control. Hela cells incubated only in protein block solution showed no immunoreactivity (Figure 2A) while Hela cells that were incubated in anti-HSP72 antibody demonstrated localization of heat shock protein in the cytoplasm (Figure 2B).

A

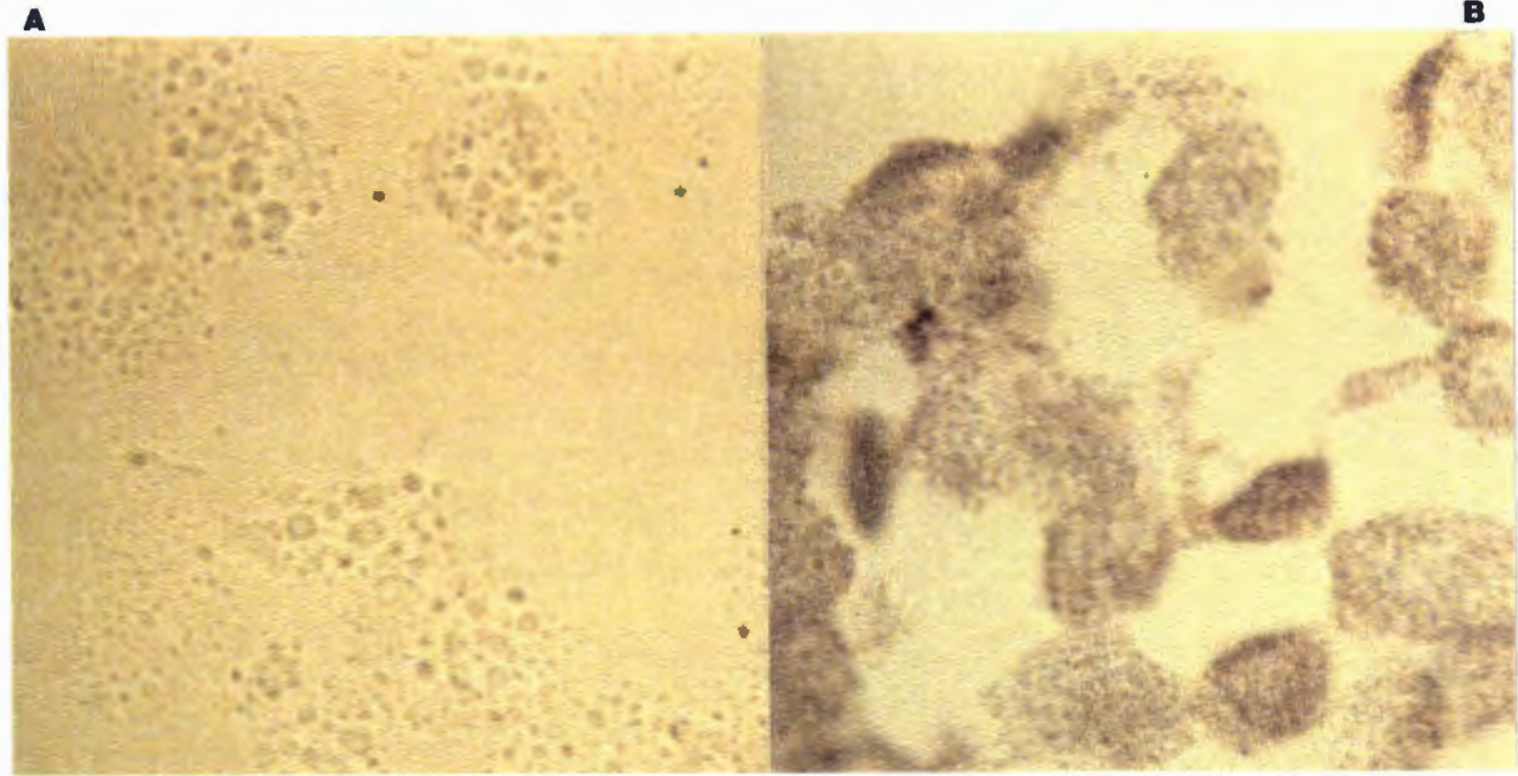

Figure 2. Hela cells (magnification, X1000). (A)

Negative control HeLa cells demonstrate no immunoreactivity (background staining) during incubation with protein blocking solution. (B) Positive control Hela cells in the cytoplasm show granular immunoreactivity with SPA 810 AP indicating presence of HSP72. The substrate employed to develop this reaction is NBT/BCIP. Further methodology in text. 
Intestinal tissue controls included the tenth day of infected intestine incubated with protein blocking agent in comparison with the same day infected intestine (Figure. 3A, 3B). Figure 3A, a control slide, illustrates the endogenous or "background" alkaline phosphatase staining around the perimeter of the intestinal villi since there is no incubation in antibody (Goor 1989). Alkaline phosphatase is a normal endogenous membrane-bound enzyme responsible for transporting calcium from the interior of the villi to the exterior (Wheater 1990). This enzyme appears to increase during the infection as seen in the sections.

In comparison to Figure 3B, another tenth day infection slide which was incubated in antibody, Figure $3 \mathrm{~A}$, shows no staining in the lamina propria. This suggests that the lamina propria staining in Figure $3 \mathrm{~B}$ demonstrates immunoreactivity and therefore is positive for HSP72 on the tenth day of infection.

The uninfected mouse and days of infection $2,4,6,8$, and 14 were studied as representatives of the infection. Unlike the immunoblot, immunoreactivity was noted in cells of the lamina propria. Non-specific staining of alkaline phosphatase surrounds the villi of all samples included in this study as expected because of the endogenous alkaline phosphatase. 

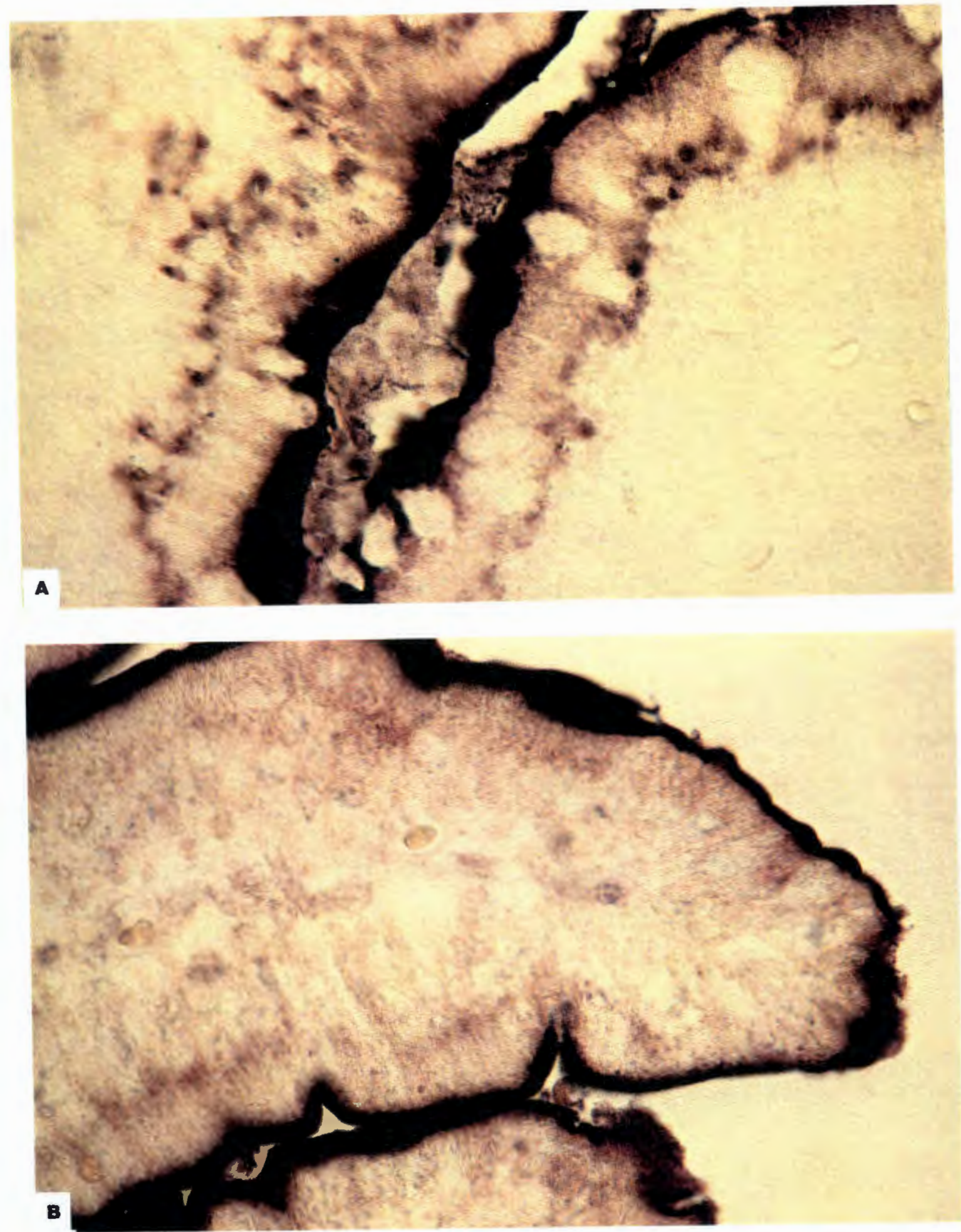

Fiqure 3. Intestinal villi tenth day of infection (magnification $\mathrm{X} 400$ ). (A) Incubation in Protein Blocking Agent (B) Incubation in anti-HSP72 demonstrating immunoreactivity. 

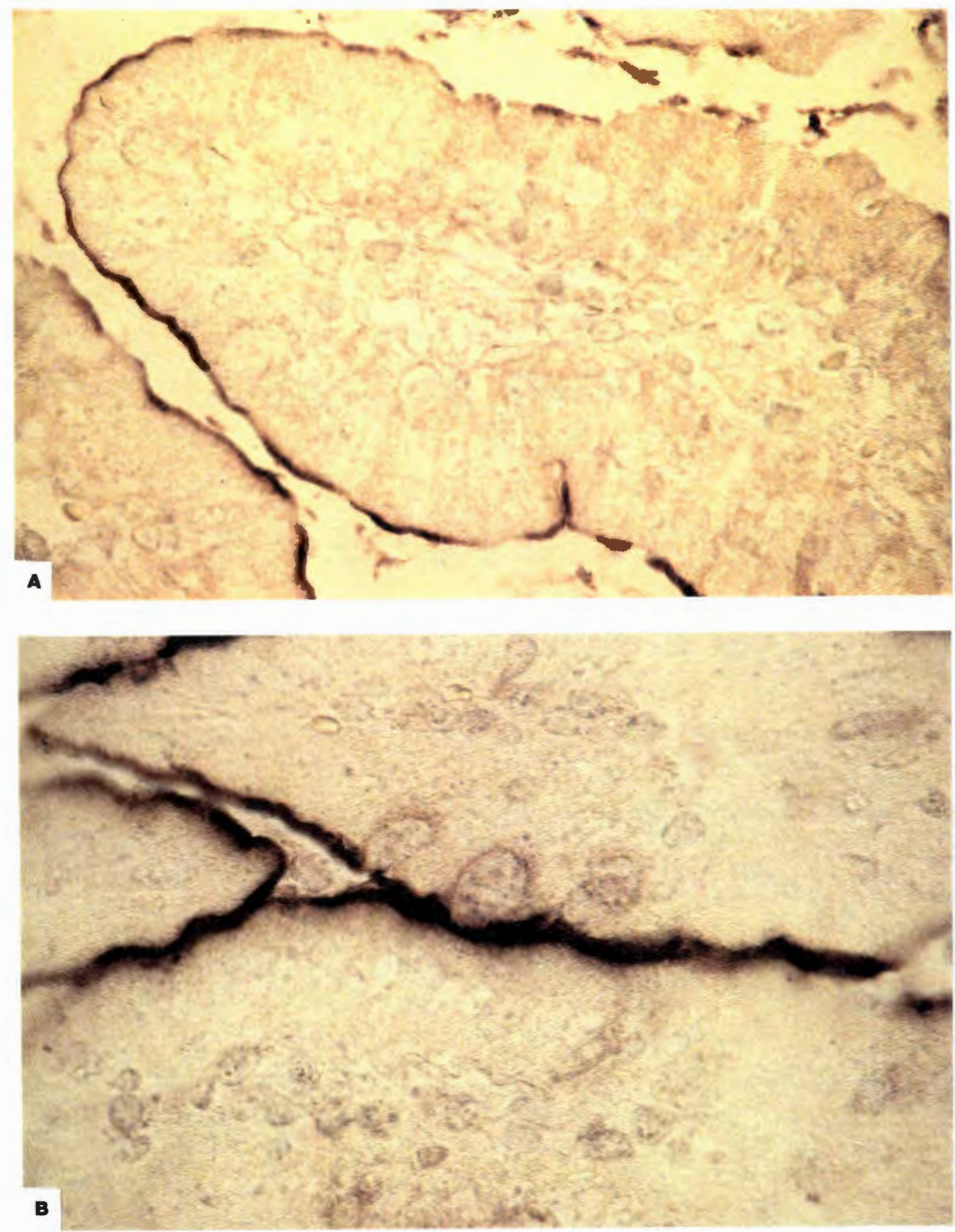

Figure 4. Intestinal villi (magnification, X400). (A) Uninfected intestinal villus. (B) Second day infected intestinal villus demonstrating minor HSP72 immunoreactivity. 

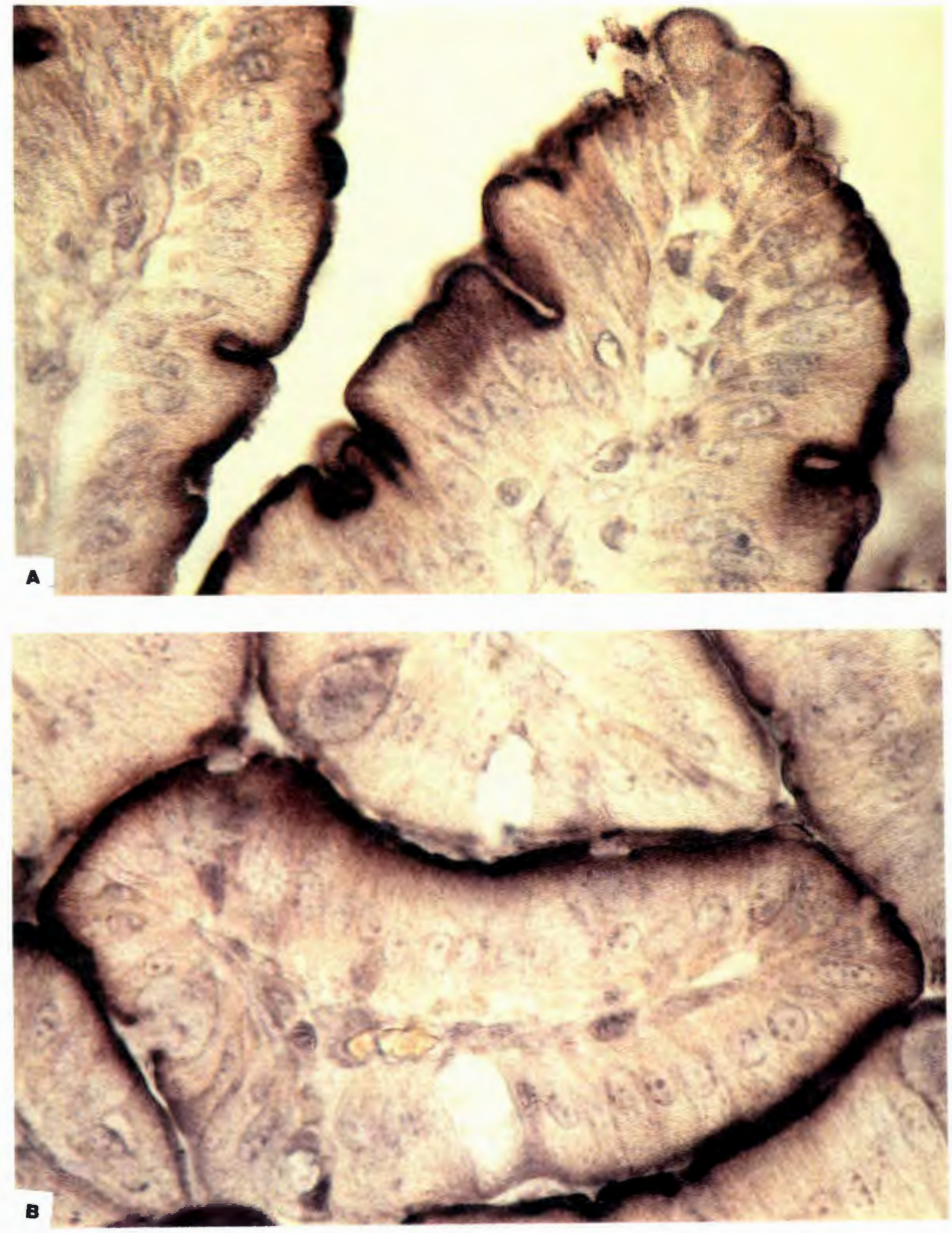

Fiqure 5. Infected intestinal villi incubated in anti-HSP72 antibody demonstrating increasing immunoreactivity (magnification X400). (A) Fourth day of infection. (B) Sixth day of infection. 

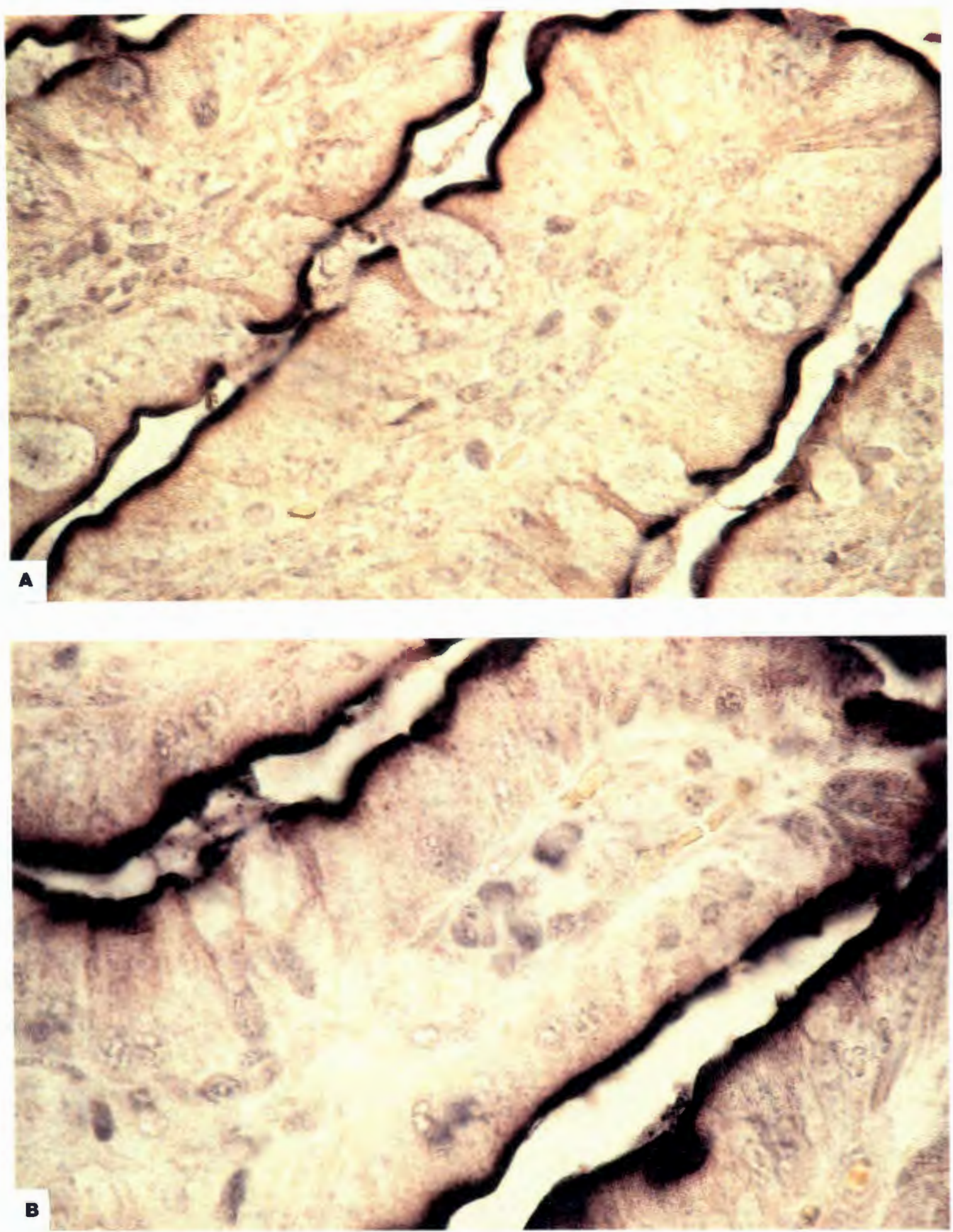

Figure 6. Infected intestinal villi demonstrating increasing immunoreactivity with HSP-72 (magnification, X400). (A) Eighth day of infection. (B) Fourteenth day of infection. 


\section{DISCUSSION}

HSP production has been linked with inflammation in several studies. Hydrogen peroxide and free radicals, known by-products of inflammation, have been linked to HSP production (Polla 1988). Furthermore, damaged or abnormal proteins, a common result of inflammation, also stimulate synthesis of stress proteins. (Hightower and white 1981). Consequently, the likelihood of linking the intestinal phase of a Trichinella infection with HSP72 production in the mouse intestinal cells was highly probable.

The immunohistochemical data in this study revealed the presence of HSP72 in the mouse intestine during a Trichinella infection. Amounts of HSP72 clearly increased during the two-week period of infection, demonstrating an interaction between the parasite and host cells. specifically, immunoreactivity increased in the lamina propria of the intestinal villi, suggesting increased migration of immune cells. Presumably, the cells that migrated into the region were lymphocytes, mast cells, eosinophils, neutrophils, and macrophages (Castro and Bullick 1983). These cells, with their toxic metabolites and subsequent local tissue damage via inflammation, have been implicated in HSP induction (Santoro et al. 1989). Their increased migration probably is directly related to 
the Trichinella infection in the epithelial layer of the mucosa and represents part of the host's immune response. The constitutive member of the HSP70 family, HSP73 responds to the same stimuli as the inducible member of the HSP70 family, HSP72. In an immunohistochemical analysis, Komatsuda et al. (1992) demonstrated an increase in HSP73 content in rats with puromycin aminonucleoside nephrosis; however, they could not detect increased HSP73 bands by immunoblotting when using whole renal extracts. An immunoblot seemed unable to detect the increase of HSP73 production when immunohistochemistry did detect this change. These results are similar to this study which could not detect the inducible HSP72 using an immunoblot but detected and demonstrated a net increase in HSP72 immunoreactivity during the infection via immunohistochemistry.

Komatsuda et al. (1992) reported a HSP73 increase in the cytoplasm of the glomerular and tubular epithelial cells. This result is different from many cultured cells which demonstrate HSP73 in the cellular nuclei directly after heat shock. Cultured cells show an increased level in the cytoplasm before stress or after recovery from heat shock (Suzuki and Watanabe 1992). This is also a characteristic of Hela cells which demonstrate cytoplasmic HSP72 after overnight recovery from heat shock. UnIike HSP72, HSP73 has been demonstrated only in the cytoplasm and nucleus. HSP72 is located in the nucleolus as 
well as in the cytoplasm and nucleus. In this study, HSP72 was present in the nucleolus, nucleus and partially in the cytoplasm of the cells in the lamina propria indicating a stress response. Epithelial cells in the earlier days of the infection show immunoreactivity in nucleoli. Aggravation in the epithelial region resulting in augmented HSP72 production may be the result of the worm's movements during feeding, mating and the expulsion of male worm after breeding. Furthermore, the parasites' intracellular location in the epithelial mucosa may disrupt intracellular proteins, requiring the synthesis of the stress protein HSP72 even though disruption sufficient to cause cell death does not occur.

The cells in the lamina propria demonstrate immunoreactivity mostly in the nucleolus and nucleus most likely are immune system cells which infiltrated the region. Further examination of hematoxylin and eosin slides of the same infection suggest that lymphocytes, mast cells, macrophages, polymorphonuclear neutrophils and eosinophils appear to be present. Castro and Bullick (1983) also noted this migration of these immune cells during a Trichinella spiralis infection. Since all are implicated in the production of HSP either by antigenic worm products or by the immune cells' own products (eg., prostaglandins or toxic oxygen species), results showing HSP72 production in intestinal cells were expected. 
These findings support another immunohistochemical evaluation that used the same antibody, Stress-Gen's anti HSP72. Heufelder et al. (1992) detected enhanced production of HSP72 in Grave's disease and Hashimoto's thyroiditis patients' thyroid follicles as well as Iymphocytic infiltrates. They attributed this phenomenon to chronic cellular stress involved in both diseases. Immunoreactivity to HSP72 was diffusely distributed throughout the cytoplasm and focally noted in the nuclei of thyroid follicular epithelial cells. Not surprisingly, the strongest HSP72 reactivity was in tissue adjacent to the areas of lymphocytic infiltration. Within this inflammatory cell infiltrate, HSP72 expression was noted in cells recognized as $B$ and $T$ cells (Heufelder et al. 1992).

The presence of this HSP may be the result of cellular damage due to chronic stress which is comparable to an infection with Trichinella involving acute stress during the inflammatory response. Nevertheless, most of the HSP72 was noted in the nuclei and nucleolus of the intestinal cells rather than the cytoplasm.

Still another study by Nagasawa et al. (1992) demonstrates the production of a HSP in mouse peritoneal cells following infection with the low virulence (Beverly) strain of Toxoplasma gondii. Highly virulent Toxoplasma only killed the host organism and did not allow the host HSP to be produced by and placed on the infected macrophages. 
Host HSP production was attributed to the parasite's ability to persist in host macrophages for a lengthy period of time allowing HSP expression on the surface of its own macrophage. HSP may participate in the elimination of the pathogen as a consequence of processing and presenting foreign antigen for effective immunity. Therefore, HSP expression on macrophages may be presented to $\mathrm{T}$ cells which will induce further cellular and humoral immunity. Nagasawa et al. (1992) concluded that HSP induction is linked to protection of the host against the destructive parasite. Host HSP may serve a similar role in other parasitic infections including Trichinella spiralis.

In conclusion, the excess influx of immune system cells including $\mathrm{T}$ lymphocytes, mast cells, eosinophils, and phagocytic cells not only produced the metabolites linked with HSP70 production but also may themselves make HSP72. The hematoxylin and eosin stained slides representing the same days of the tissues used for immunohistochemistry suggest the presence of a variety of immune cells in the lamina propria which may be responsible for the enhanced production of the HSP72 protein during the two week study. 


\section{LITERATURE CITED}

Beckmann, R.P. (1990). Interaction of HSP 70 with Newly Synthesized Proteins: Implications for Protein Folding and Assembly. Science. 248: 850-854.

Befus, Dean (1986). Immunity in Intestinal Helminth Infections: Present Concepts, Future Directions: Transactions of the Royal Society of Tropical Medicine and Hygiene. 80: 735-741.

Bell, R., W.M. Liu (1988). Trichinella spiralis: Quantitative Relationships between Intestinal worm Burden, Worm Rejection, and the Measurement of Intestinal Immunity in Inbred Mice. Experimental Parasitology. 66: 44-56.

Burel, C., V. Mezger, M. Pinto, M. Rallu, S. Trigon and M. Morange. (1992) Mammalian Heat Shock Protein Families. Expression and Functions. Experientia (48): 629-634.

Castro, G.A. (1989). Immunophysiology of Enteric Parasitism. Parasitology Today. 5 (1): 11-19.

Castro, G.A., G.R. Bullick (1983). Pathophysiology of the Gastrointestinal Phase. p.209, Trichinella \& Trichinosis. New York: Plenum Press.

Chappell, Thomas G., W.J. Welch, D.M. Schlossman, K.B. Palter, M.J. Schlesinger, J.E. Rothman. (1986) Uncoating ATPase Is a Member of the 70kD Family of Stress Proteins. Cell. 45: 3-13.

Cheng, Thomas C (1986). General Parasitology. Orlando, Fl: Academic Press.

Craig, E.A. (1993). Chaperones: Helpers Along the Pathways to Protein Folding. Science. 260: 1902-1904.

Despommier, D.D. (1983). Biology. Trichinella \& Trichinosis. p. 75, New York: Plenum Press.

DeVos, Theo, G. Danell, T. Dick (1992). Trichinella spiralis: Dose Dependence and Kinetics of the Immune Response in Mice. Experimental Parasitology 75: 99111 . 
Donati, Y.R.A., D.O. Slosman, B.S. Polla.(1990). Oxidative Injury and the Heat Shock Response. Biochemical Pharmacology. 40(12): 2571-2577.

Feige, U., J. Mollenhauer. (1992). Heat Shock Proteins. Experientia 48: 621-622

Ferris, D.K., A. Harel-Bellan, R.I. Morimoto, W.J. Welch. (1988). Mitogen and Lymphokine stimulation of Heat Shock Proteins in $\mathrm{T}$ Lymphocytes. Proc.Natl.Acad.Sci. 85: $3850-3854$.

Fincato, G., N. Polentarutti, A. Sica, A. Mantovani, F. Colotta. (1991). Expression of a Heat-Inducible Gene of the HSP70 Family in Human Myelomonocytic Cells: Regulation by Bacterial products and Cytokines. Blood. $77: 579-586$.

Fridovich, I. (1978). The Biology of Oxygen Radicals. Science. 201: 875-879.

Goor, H.V. P.O. Gerrits, M.J. Hardonk. (1989). Enzyme Histochemical Demonstration of Alkaline Phosphatase Activity in Plastic-embedded Tissues Using a Gomoribased Cerium-DAB Technique. Journal of Histochemistry and Cytochemistry. 37 (3): 399-403.

Gould, S.E.,M.D. (1970). Trichinosis in Man and Animals. Springfield, Ill.: Charles C Thomas.

Heufelder, A.E., J.R. Goellner, B.E. Wenzel, and R.S. Bahn. (1992). Immunohistochemical Detection and Localization of a 72-Kilodalton Heat Shock Protein in Autoimmune Thyroid Disease. Journal of Clinical Endocrinology. 74 (4): 724-730.

Hightower, L.E., F. White (1981). Cellular Responses to Stress: Comparison of a Family of 71-73-Kilodalton Proteins Rapidly Synthesized in Rat Tissue Slices and Canavanine-Treated Cells in culture. Journal of Cellular Physiology. 108: 261-275.

Kaufmann, S.H.E. (1990). Heat Shock Proteins and the Immune Response. Immunology Today. 11 (4): 129-136.

Kazacos, K.R., A.S. Little, F.J. Rohe, W.F. Wade, and S.m. Gaafar (1986). A Tongue Biopsy Technique for the Detection of Trichinosis in Swine. Veterinary Parasitology 19: 151-156.

Komatsuda, A., H. Wakui, H. Imai, Y. Nakamoto, A.B. Miura, H. Itoh, and Y. Tashima. (1992). Renal Localization of 
Komatsuda, A., H. Wakui, H. Imai, Y. Nakamoto, A.B. Miura, H. Itoh, and Y. Tashima. (1992). Renal Localization of the Constitutive 73-kDa Heat-shock Protein in Normal and PAN Rats. Kidney International. 41: 1204-1212.

Kumar, S.N., G.I. Stewart, L.L. Seelig (1989). Maternal to Neonatal Transmission of $\mathrm{T}$-cell Mediated Immunity to Trichinella spiralis During Lactation. Immunology 68: 87-92.

Laemmli, UK. (1970) Cleavage of structural Proteins During the Assembly of the Head of Bacteriophage T4. Nature. 227 : $680-685$.

Linquist, S. (1986). The Heat-Shock Response. Annual Review of Biochemistry. 55: 1151-1191.

Linquist, S., E.A. Craig. (1988) The Heat-Shock Proteins. Annual Review of Genetics. 22: 631-677.

Moqbel, R. (1986). Helminth-induced Intestinal Inflammation. Transactions of Royal Society of Tropical Medicine and Hygiene. 80: 719-727.

Nagasawa, H., M. Oka, K. Maeda., C. Jian-Guo, H. Hisaeda, Y. Ito, R.A. Good, and K. Himeno. (1992). Induction of Heat Shock Protein Closely correlates with Protection Against Toxoplasma gondii Infection. Proc.Natl.Acad. Sci. $89: 3155-3158$.

Pappolla, M.A, R.A. Omar, K.S. Kim, N.K. Robakis. (1992). Immunohistochemical Evidence of Antioxidant stress in Alzheimer's Disease. American Journal of Pathology. 140 (3): $621-628$.

Polla, B.S. (1991). Heat Shock Proteins in Host-Parasite Interactions. Immunoparasitology Today. 12(3)7(3): A38A41.

Polla, B.S., S. Kantengwa. (1991). Heat shock proteins and Inflammation. Current Topics in Microbiology and Immunology. 167: 93-195.

Polla, B.S. (1988). A Role for Heat Shock Proteins in Inflammation? Immunology Today. 9 (5): 134-137.

Pond, L., D.I. Wassom, C.E. Hayes. (1989). Evidence for Differential Induction of Helper $T$ Cell Subsets During Trichinella spiralis Infection. The American Association of Immunologists. 143: 4232-4237. 
Preece, Ann. (1972). A Manual for Histologic Technicians. Boston: Little, Brown and Company.

Ritossa, F.(1962). A New Puffing Pattern Induced by Temperature Shock and DNP in Drosophila. Experientia 18. 571-573.

Roitt, Ivan, Brostoff,J, Male, David (1989). Immunology. p.4, London: Gower Medical Publishing.

Santoro, M.G., Garaci, E., Amici, C. (1989). Prostaglandins with Antiproliferative Activity Induce the Synthesis of a Heat Shock Protein in Human Cells. Proc.Nat1.Acad.Sci.86: 8407-8411.

Suzuki, K. and Masami Watanabe (1992). Biochemical and Biophysical Research Communication. 186 (3): 1257-1264.

Takenaka, I.M., and L.E. Hightower. (1992). Transforming Growth Factor-Betal Rapidly Induces HSP70 and HSP9O Molecular Chaperones in Cultured Chicken Embryo Cells. Journal of Cellular Physiology. 152: 568-577.

Tissieres, A., H.K. Mitchell, U. Tracy. (1974). Protein Synthesis in Salivary Glands of Drosophila maelanogaster. Relation to Chromosome Puffs. Journal of Molecular Biology. 84: 389-398.

Towbin H., T. Staehelin, J Gordon. (1979). Electrophoretic Transfer of Proteins from Polyacrylamide Gels to Nitrocellulose Sheets: Procedure and Some Applications. Proc.Natl.Acad.Sci. 76: 4350-4354.

Vass, K., W.J. Welch, T.S. Nowak, Jr.(1988). Localization of 70-kDa stress Protein Induction in Gerbil Brain After Ischemia. Acta Neuropathologica. 77: 128-135.

Wakelin, D. (1984). Immunity to Parasites. East Kilbride, Scotland: Edward Arnold.

Wakelin, D., D.A. Denham. (1983). The Immune Response. p. 265. Trichinella \& Trichinosis. New York: Plenum Press.

Weatherly, N.F. (1983). Anatomical Pathology. Trichinella \& Trichinosis. p. 173. New York: Plenum Press

Welch, W.J. (1993). How Cells Respond to Stress. Scientific American. 268 (5): 56-64.

Welch, W.J. (1991). Responses of Mammalian Cells To Metabolic Stress. Current Topics in Microbiology and Immunology. 167: 35-42. 
Welch, W.J. and J.P. Suhan (1986). Cellular and Biochemical Events in Mammalian Cells During and After Recovery from Physiological stress. Journal of Cell Biology. 103: 2035-2052.

Wheater, P.R., H.G. Burkitt, V.G. Daniels.(1990). Functional Histology. p, 221. New York: Churchill Livingstone.

Young, R.A. (1990). Stress Proteins and Immunology. Annual Review of Immunology. 8: 401-420.

Zhang, S., G.A. Castro. (1990). Involvement of Type I Hypersensitivity in Rapid Rejection of Trichinella spiralis from Adult Rats. Int Arch Allergy Appl Immunol. 93: 272-279. 
APPENDIX A

STOCK SOLUTIONS FOR IMMUNOBLOT 
APPENDIX A

STOCK SOLUTIONS FOR IMMUNOBLOT

TABLE I

SAMPLE SOLUTIONS

Sample/Lysis Buffer

$20 \%$ SDS............ $5.0 \mathrm{ml}$

Tris (Sigma-1M, pH 7.0) $2.5 \mathrm{ml}$

Sucrose................ $\mathrm{g}$

$\mathrm{ddH}_{2} \mathrm{O} \ldots \ldots \ldots \ldots$.......... $7.5 \mathrm{ml}$

Before use add:

Bromophenol Blue.......5 ul

2-mercaptoethanol....5 ul to

95 ul sample buffer

Cell Lysate Solution--RIPA

Tris-HCl (50mM pH 7.2).785 mg

$\mathrm{NaCl}$ (150mM) ........8876 mg

$\mathrm{NP}-40 \quad(1 \%) \ldots \ldots \ldots \ldots . .1 .0 \mathrm{ml}$

$\mathrm{Na}$ deoxycholate $(1 \%) \ldots . .0 \mathrm{~g}$

SDS $(0.1 \%) \ldots \ldots \ldots \ldots \ldots .1 \mathrm{~g}$

$\mathrm{ddH}_{2} \mathrm{O} \ldots \ldots \ldots \ldots$....... $100 \mathrm{mI}$

\section{TABLE II}

SDS-PAGE STOCK SOLUTIONS

Monomer solution $(30 \% \mathrm{~T}, 2.7 \% \mathrm{Cbis})$

Acrylamide..........58.4 g

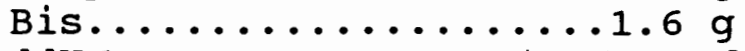
$\mathrm{ddH}_{2} \mathrm{O} \ldots \ldots \ldots \ldots \ldots$ to $200 \mathrm{ml}$

stored at $4^{\circ} \mathrm{C}$. in dark

$4 \times$ Running Gel Buffer

(1.5M Tris-Cl, pH 8.8)

Tris(Baker) ........18.15 g

Adjust to $\mathrm{pH} 8.8$ with $10 \mathrm{~N} \mathrm{HCl}$

$\mathrm{ddH}_{2} \mathrm{O} \ldots \ldots \ldots \ldots$....... $100 \mathrm{ml}$ 
TABLE II

SDS-PAGE STOCK SOLUTIONS (continued)

$4 X$ stacking Gel Buffer

(0.5M Tris-Cl, $\mathrm{pH} 6.8$ )

Tris (Baker) .............. g g

Adjust to $\mathrm{pH} 6.8$ with $10 \mathrm{~N} \mathrm{HCl}$

$\mathrm{ddH}_{2} \mathrm{O} \ldots . . . . . .$. to.... $50 \mathrm{ml}$

$10 \%$ SDS (Sigma)

SDS................60 g

$\mathrm{ddH}_{2} \mathrm{O} \ldots \ldots \ldots . . . . .$. to $600 \mathrm{ml}$

Initiator

(10\% ammonium persulfate)

Ammonium persulfate...10.0 g

$\mathrm{ddH}_{2} \mathrm{O} \ldots \ldots \ldots \ldots . .$. ........ $10.0 \mathrm{ml}$

Aliquot and Freeze -20 deg $C$.

Electrophoretic Buffer

(0.025 M Tris, 0.192 M glycine,

$0.1 \%$ SDS, $\mathrm{pH} \mathrm{8.3)}$

Tris (Baker)............. g

Glycine (Sigma) ......28.8 g

$\operatorname{sDs}(10 \%) \ldots \ldots \ldots . . . .20 \mathrm{ml}$

$\mathrm{ddH}_{2} \mathrm{O} \ldots \ldots \ldots \ldots . . .$. to 2.01

Stain

(0.025\% Cambist Blue R-250, 40\%

Methanol, 7\% Glacial Acetic Acid)

Cambist Blue.......0.25 g

Methanol...........400 ml

Stir until dissolved

Glacial Acetic Acid....70 ml

$\mathrm{ddH}_{2} \mathrm{O} \ldots \ldots . .$. ........ to 1.01

Destain

(50\% methanol, $10 \%$ glacial acetic)

Methanol...........500 ml

Glacial acetic acid....100 ml

$\mathrm{ddH}_{2} \mathrm{O} \ldots \ldots . .$. .......to 1.01

Gel Storage solution

(16\% isopropanol, $10 \%$ glycerol

$1 \%$ acetic acid)

Isopropanol........4.48 ml

Glycerol...............30 ml

Glacial Acetic Acid....3.0 ml

$\mathrm{ddH}_{2} \mathrm{O} \ldots \ldots \ldots \ldots \ldots . \ldots 219 \mathrm{ml}$ 
TABLE III

WESTERN BLOT SOLUTIONS

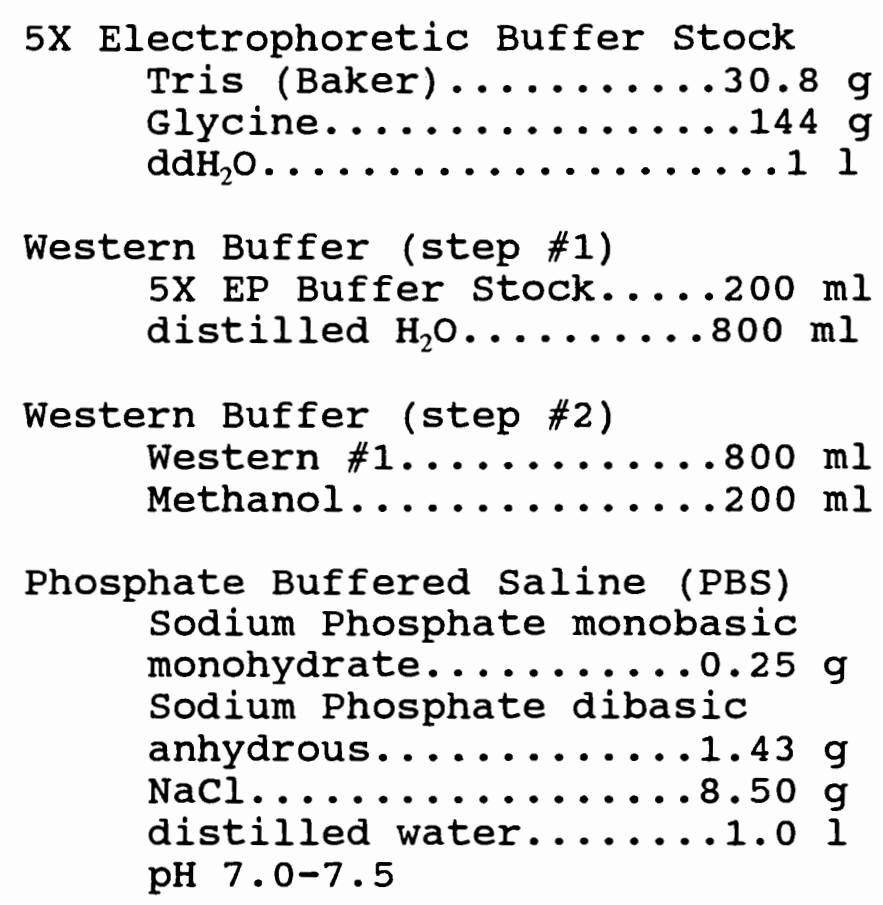


APPENDIX B

HEMATOXYLIN AND EOSIN PROTOCOL 
APPENDIX B

HEMATOXYLIN AND EOSIN PROTOCOL

1. Deparaffinize with 3 changes of xylene, 5 minutes each.

2. Wash in $100 \%$ (anhydrous) ethanol, 3 changes, 1 minute each.

3. Wash in $95 \%$ ethanol 1 minute each.

4. Wash in $80 \%$ ethanol 1 minute each.

5. Wash in $70 \%$ ethanol 1 minute each.

6. Stain in Gill II hematoxylin for 2 minutes. (Longer time required for older solutions.)

7. Wash in running tap water for 1 minute.

8. Blue in Trizma, pH 7.6 base for 15-30 seconds.

9. Wash thoroughly in running tap water, 3-5 minutes, to remove excess Trizma.

10. Wash in $70 \%$ ethanol for 1 minute.

11. Stain in eosin for 1 minute.

12. Wash in $80 \%$ ethanol for 1 minute.

13. Wash in $95 \%$ ethanol for 1 minute.

14. Dehydrate in 100\% (anhydrous) ethanol for 1 minute.

15. Clear in xylene, 3 changes, 1 minute each.

16. Coverslip sections using permount. 